\title{
Study of pattern of nosocomial infections among post-operative patients following obstetrical and gynaecological surgeries in a tertiary care institute of northern India
}

\author{
Latika*, Smiti Nanda, Pushpa Dahiya, Sushila Chaudhary
}

Department of Obstetrics and Gynecology, PT. B. D. Sharma, PGIMS, Rohtak, Haryana, India

Received: 20 January 2019

Accepted: 05 March 2019

\author{
*Correspondence: \\ Dr. Latika, \\ E-mail: latika.duhan@gmail.com
}

Copyright: () the author(s), publisher and licensee Medip Academy. This is an open-access article distributed under the terms of the Creative Commons Attribution Non-Commercial License, which permits unrestricted non-commercial use, distribution, and reproduction in any medium, provided the original work is properly cited.

\begin{abstract}
Background: Hospital acquired infections (HAIs) are the major causes of morbidity and mortality, functional disability and financial burden among the patients admitted in hospitals. The nosocomial infection has thrown a big challenge to the health sector in both the developing and developed countries; therefore, it is important to put in place surveillance system for monitoring its incidence rate and planning early interventions for its prevention. The aim and objective of the study was to study the socio demographic profile of the patients who underwent Obstetrical and Gynecological surgeries and to identify the risk factors and causative organisms associated with the post-operative nosocomial infection and pattern of antibiotics sensitivity.

Methods: It was a record based retrospective study carried out in a tertiary care referral institute. The case files of all post-operative patients from January 2015 to July 2015 were retrieved from the Medical Record department and an extensive analysis was carried out.

Results: It was found that majority of the patients (75\%) with nosocomial infection were in the age group of 20-35 years and all were married. Most of them (72\%) were from the rural background. It was observed that around $9 \%$ patients reported nosocomial infection after emergency laparotomy procedure as compared to $8 \%$ of patients after elective procedure.

Conclusions: In this study it was found that surgical site infection (SSI) was most common nosocomial infection followed by Urinary tract infection. The majority of surgical site infections can be prevented by the preoperative, intraoperative and postoperative phases of care.
\end{abstract}

Keywords: Antibacterial, Hospital acquired infections, Surgical site infection, UTI

\section{INTRODUCTION}

Hospital acquired infections (HAIs) are the major causes of morbidity and mortality, functional disability and financial burden among the patients admitted in hospitals. $^{1,2}$ The commonest type of hospital acquired infection are surgical wound and other soft tissue infections followed by urinary tract, respiratory and blood stream infections." "It was reported that the incidence of wound complications in the obstetric population varies from $2.8 \%$ to $26.6 \%$ " ${ }^{5-7}$ The patients who underwent caesarian section have more chances of acquiring HAI due to many reasons viz. perioperative bacterial load at the site of incision, anemia, obesity, increased blood loss during surgery, prolonged labour etc. Thus, even if the patient has no symptom of active infection, the obstetrical surgeries are grouped under 'clean-contaminated' cases. ${ }^{8}$ The nosocomial infection has thrown a big challenge to 
the health sector in both the developing and developed countries; therefore, it is important to put in place surveillance system for monitoring its incidence rate and planning early interventions for its prevention.

Therefore, present study was conducted at a tertiary care and referral institute of North India to find out the incidence of various nosocomial infections, sociodemographic profile of patients with postoperative infections, various high risks factors, most common causative organisms and pattern of antibiotic sensitivity.

The aim and objectives are to study the socio demographic profile of the patients who underwent Obstetrical and Gynecological surgeries and to identify risk factors and causative organisms associated with the post operative nosocomial infection and pattern of antibiotics sensitivity.

\section{METHODS}

It was a record based retrospective study carried out in a tertiary care referral institute. The case files of all postoperative patients from January 2015 to July 2015 were retrieved from the Medical Record department and an extensive analysis was carried out.

\section{Inclusion criteria}

- The indoor files of postoperative patients from period January 2015 to July 2015 were included.

\section{Exclusion criteria}

- Few files which couldn't be traced were excluded from the study.

\section{Statistical analysis}

Descriptive statistics was used for various socio demographic variables such as age, marital status, place of residence, religion were studied. Also, frequency of surgery, whether elective or emergency, various risk factors associated with nosocomial infections, organism isolated and pattern of antibiotic sensitivity were calculated. Detailed analysis of categorical variables was carried out using Chi-square test and interpretation was done.

\section{RESULTS}

It was found that majority of the patients $(75 \%)$ with nosocomial infection were in the age group of 20-35 years and all were married. When the background was traced, it was found that Most of them (72\%) belonged to rural community (Table 1).

It was observed that around $9 \%$ patients reported nosocomial infection after emergency laparotomy procedure as compared to $8 \%$ of patients after elective procedure. It was also found that no patient reported nosocomial infection after elective LSCS, however $5.1 \%$ patients reported HAI after emergency LSCS. In contrary it was seen that the HAI was $5 \%$ in elective TAH and no case with HAI was reported after emergency total abdominal hysterectomy (TAH) procedure.

Table 1: Socio demographic profile of patients having nosocomial infection $(n=64)$.

\begin{tabular}{|l|l|l|}
\hline \multirow{2}{*}{ Item } & \multicolumn{1}{c|}{$\begin{array}{c}\text { Total no. and } \\
\text { percentage }\end{array}$} \\
\hline \multirow{2}{*}{ Age } & $<20$ years & $2(3.13 \%)$ \\
\cline { 2 - 3 } & 20-35 years & $48(75 \%)$ \\
\hline Marital status & Married & $14(21.9 \%)$ \\
\hline \multirow{2}{*}{ Residence } & Urban & $64(100 \%)$ \\
\hline Religion & Rural & $46(28.13 \%)$ \\
\hline
\end{tabular}

This bias was probably due to less number of total abdominal hysterectomy (TAH) being done as an emergency procedure. It was found that surgical site infection $(89.1 \%)$ was the most common nosocomial infection followed by urinary tract infection (UTI) $(9.4 \%)$, followed by respiratory tract infection $(1.56 \%)$ (Table 2).

Table 2: Incidence of post-operative infection.

\begin{tabular}{|c|c|c|c|c|c|c|}
\hline \multirow{2}{*}{\multicolumn{2}{|c|}{ Type of surgery }} & \multirow{4}{*}{$\begin{array}{l}\text { Total no. of } \\
\text { patients } \\
74 \\
87\end{array}$} & \multirow{4}{*}{$\begin{array}{l}\text { Total no. of patients with } \\
\text { post operative infection } \\
6(8.11 \%) \\
8(9.2 \%)\end{array}$} & \multicolumn{3}{|c|}{ Type of nosocomial infection } \\
\hline & & & & \multirow{3}{*}{$\begin{array}{l}\text { UTI } \\
01\end{array}$} & \multirow{3}{*}{$\begin{array}{l}\text { SSI } \\
13\end{array}$} & \multirow{3}{*}{ RTI } \\
\hline \multirow{2}{*}{ Laparotomy } & Elective & & & & & \\
\hline & Emergency & & & & & \\
\hline \multirow{2}{*}{ LSCS } & Elective & 121 & 0 & \multirow{2}{*}{05} & \multirow{2}{*}{38} & \multirow{2}{*}{01} \\
\hline & Emergency & 851 & $44(5.2 \%)$ & & & \\
\hline \multirow{2}{*}{ TAH } & Elective & 93 & $5(5.4 \%)$ & \multirow{2}{*}{-} & \multirow{2}{*}{05} & \multirow{2}{*}{-} \\
\hline & Emergency & 2 & 0 & & & \\
\hline \multirow{2}{*}{ Others } & Elective & 61 & $1(1.64 \%)$ & \multirow{2}{*}{ - } & \multirow{2}{*}{01} & \multirow{2}{*}{-} \\
\hline & Emergency & 1 & 0 & & & \\
\hline \multicolumn{2}{|l|}{ Total } & 1290 & 64 & $06(9.4 \%)$ & $57(89.1 \%)$ & $01(1.56 \%)$ \\
\hline
\end{tabular}


Table 3: Details of risk factors in patients with nosocomial infection.

\begin{tabular}{|l|l|l|}
\hline Risk factors & Total no. of patients studied & Total no. of patients with risk factors \\
\hline Obesity & 64 & $7(10.94 \%)$ \\
\hline Previous surgical scar & 64 & $22(34.38 \%)$ \\
\hline Anaemia & 64 & $38(59.38 \%)$ \\
\hline $\begin{array}{l}\text { Gynecological malignancy } \\
\text { Immunocompromised state }\end{array}$ & 64 & $8(12.5 \%)$ \\
\hline \begin{tabular}{l|l|} 
Post CT \\
HTN, Preeclampsia
\end{tabular} & 64 & $4(6.25 \%)$ \\
\hline $\begin{array}{l}\text { Duration of labour >24 hours before } \\
\text { surgery (in case of LSCS) }\end{array}$ & 64 & $2(3.13 \%)$ \\
\hline $\begin{array}{l}\text { Duration of rupture of membranes >12 } \\
\text { hours before surgery (In case of LSCS) }\end{array}$ & 44 & $2(3.13 \%)$ \\
\hline $\begin{array}{l}\text { Chorioamnitis (in case of LSCS) } \\
\text { MSL (in case of LSCS) }\end{array}$ & 44 & $5(7.82 \%)$ \\
\hline $\begin{array}{l}\text { Volume of intraoperative } \\
\text { blood loss }\end{array}$ & 44 & $1(1.56 \%)$ \\
\hline \begin{tabular}{l} 
Preoperative BT \\
\hline
\end{tabular} & 64 & $11(17.19 \%)$ \\
\hline
\end{tabular}

It was revealed that anemia was the most common risk factor $(59.38 \%)$ followed by previous surgical scar (34.38\%), HTN, Preeclampsia (29.69\%), and preoperative BT $(21.88 \%)$ (Table 3$)$.

Out of all patients with nosocomial infections, $90.62 \%$ of patients had surgical site infections. It was found that Staphylococcus aureus was the most common causative agent $(22.4 \%)$ of nosocomial infections followed by Acinetobacter $(12.06 \%)$, E. coli $(5.17 \%)$. It was also found that in 19 cases, no microorganism was reported in culture report and the culture report was not found in 17 case files (Table 4).

Table 4: Type of microorganism.

\begin{tabular}{|l|l|l|}
\hline $\begin{array}{l}\text { Type of } \\
\text { microorganism }\end{array}$ & $\begin{array}{l}\text { Urinary tract } \\
\text { infection } \\
\text { (UTI) }\end{array}$ & $\begin{array}{l}\text { Surgical site } \\
\text { infection } \\
\text { (SSI) }\end{array}$ \\
\hline $\begin{array}{l}\text { Staphylococcus } \\
\text { aureus }\end{array}$ & - & 13 \\
\hline E. coli & 01 & 03 \\
\hline P. aeruginosa & - & 01 \\
\hline Acinetobacter & - & 07 \\
\hline Enterococcus & - & 01 \\
\hline Citrobacter & - & 02 \\
\hline Organism not found & 02 & 17 \\
\hline $\begin{array}{l}\text { Culture and sensitivity } \\
\text { report not available }\end{array}$ & 03 & 14 \\
\hline
\end{tabular}

In $9.375 \%$ of total patients, UTI was detected. It was found that most of the cases with Surgical site infections were sensitive to Doxycycline $(24.137 \%)$ followed by Linezolid (22.41\%), Imipenem (18.965\%), Cephalosporins (15.51\%) and other drugs (Table 5).
Table 5: Details of drug sensitivity in different type of nosocomial infections.

\begin{tabular}{|c|c|c|}
\hline \multirow[t]{2}{*}{ Type of antibiotic } & \multicolumn{2}{|c|}{$\begin{array}{l}\text { Type of nosocomial } \\
\text { infection }\end{array}$} \\
\hline & UTI & SSI \\
\hline $\begin{array}{l}\text { Amoxyclav, Penicillin, } \\
\text { Amoxycillin, Ampicillin }\end{array}$ & - & 07 \\
\hline Cephalosporins (Ceftazidine) & - & 09 \\
\hline Ciprofloxacine, Ofloxacine & - & 04 \\
\hline Imepenem & 01 & 11 \\
\hline Meropenem & - & 08 \\
\hline Cotrimoxazole & - & 02 \\
\hline Doxycycline & - & 14 \\
\hline Linezolid & - & 13 \\
\hline Erythromycin & - & 09 \\
\hline Oxacillin & - & 09 \\
\hline Amikacin & - & 05 \\
\hline Pipzo & - & 01 \\
\hline Report not available & 05 & 02 \\
\hline
\end{tabular}

\section{DISCUSSION}

Nosocomial infections are an important cause of increasing morbidity in postoperative patients. It is widely prevalent in both developing as well as developed countries.

Therefore, a retrospective study was carried out in present institute to go in depth and find out the most prevalent nosocomial infection, sociodemographic profile of such patients, type of surgery, various risk factors which are commonly associated with nosocomial infections, common organisms isolated and pattern of drug sensitivity in them. 
It was found that majority of the patients $(75 \%)$ were in the age group of 20-35 years and all were married.

Most of them (72\%) were from the rural background. It was observed that around $9 \%$ patients reported nosocomial infection after emergency laparotomy as compared to $8 \%$ of patients after elective procedure.

It was also found that no patient reported nosocomial infection after elective LSCS, however $5.1 \%$ patients reported HAI after emergency LSCS. It correlates with study of Patel S et al and Satyanarayana V et al, who also showed that nosocomial infections were more common in emergency procedures as compared to elective ones. ${ }^{9,10}$

It was observed that surgical site infection (89.1\%) was the most common nosocomial infection followed by urinary tract infection (UTI) (9.4\%). It is in accordance with a study from Faso B which reported surgical site infection as being the most common type, followed by urinary tract infection and hospital-acquired pneumonia. ${ }^{11}$

It was revealed in present study that anemia was the most common risk factor $(59.38 \%)$ followed by previous surgical scar (34.38\%), HTN, Preeclampsia (29.69\%), and preoperative BT $(21.88 \%)$. It correlates well with study of Jahan I et al, in which authors found anaemia as the risk factor for surgical site infection in $52 \%$ of patients. $^{12}$

In the present study, it was observed that Staphylococcus aureus was the most common causative agent of nosocomial infections (in 22.4\%) followed by Acinetobacter $(12.06 \%)$. It is in correlation with study by Shittu et al, who showed Staphylococcus aureus being the commonest organism isolated from wound infections. ${ }^{13}$

Most of the cases in present study were sensitive to Doxycycline (24.137\%) followed by Linezolid (22.41\%), Imipenem (18.965\%) and other drugs. Contrary, to this it has been shown in many studies that Staphylococcus aureus was resistant to almost all commonly used antibiotics. $^{14-16}$

\section{CONCLUSION}

In this study it was found that surgical site infection (SSI) was most common nosocomial infection followed by urinary tract infection.

\section{Recommendations}

The majority of surgical site infections can be prevented by the preoperative, intraoperative and postoperative phases of care. Regular surveillance for nosocomial infections and ongoing periodic sensitization programmes for all categories of health care workers regarding nosocomial infections would go a long way in reducing the rate of various nosocomial infections.
Funding: No funding sources

Conflict of interest: None declared

Ethical approval: The study was approved by the Institutional Ethics Committee

\section{REFERENCES}

1. Kamat US, Ferreira AM, Savio R, Motghare DD. Antimicrobial resistance among nosocomial isolate in a teaching hospital in Goa. Indian J Comm Med. 2008;33:89-92.

2. Endalafer N, Gebre-Selassie S, Kotisso B. Nosocomial bacterial infections in a tertiary hospital in Ethiopia. J Infect Prev. 2011;12:38-43.

3. Graves N. The cost of hospital acquired infections. Unit Costs of Health and Social Care. 2000:25-27.

4. Morgan AJ, Horan TC, Pearson ML, Silver LC, Jarvis WR. The hospital infection control practices Advisory Committee: A guideline for prevention of surgical site infection. Infect Control Hospital Epidemiol. 1999;20(4):247-78.

5. Myles TD, Gooch J, Santolaya J. Obesity as an independent risk factor for infectious morbidity in patients who undergo cesarean delivery. Obstet Gynecol. 2002;100:959-64.

6. Naumann RW, Hauth JC, Owen J, Hodgkins PM, Lincoln T. Subcutaneous tissue approximation in relation to wound disruption after caesarean delivery in obese women. Obstet Gynecol. 1995;85:412-6.

7. Chelmow D, Huang E, Strohbehn K. Closure of the subcutaneous dead space and wound disruption after cesarean delivery. J Matern Fetal Neonatal Med. 2002;11:403-8.

8. Larsen John W, Hager W, Livengood Charles H, Hoyme Udo. Guideline for the diagnosis, treatment and prevention of post operative infections. Infect Obstet Gynecol. 2003;11:65-70.

9. Patel SM, Patel MH, Patel SD, Soni ST, Kinariwala DM, Vegad MM. Surgical site infections: incidence and risk factors in a tertiary care hospital, western India. Natl J Commun Med. 2012;3(2):193-6.

10. Satyanarayana V, Prashanth HV, Basavaraj B, Kavyashree AN. Study of surgical site infections in abdominal surgeries. J Clin Diagn Res. 2011;5(October (5)):935-9.

11. Sanou J, Traore SS, Lankoande J, Ouedraogo RM, Sanou A. Survey of nosocomial infection prevalence in the surgery department of the Central National Hospital of Ouagadougou. Dakar Med. 1999;44:1058.

12. Jahan I, Siddiqui O, Ahmed SU, Joarder AI, Faruque $\mathrm{S}$, Imdad $\mathrm{S}$, et al. Wound infection in surgery department in BSMMU: A study of 100 cases. J Bangladesh Soc Anaesthesiol. 2011;24(2):65-9.

13. Shittu AO. A study of wound infections in two health institutions in lle-llf, Nigeria. Afr J Biomed Res. 2002;5:97-102.

14. Messele G, Woldemedhin Y, Demissie M, Mamo K, Geyid A. Common causes of nosocomial infections and their susceptibility patterns in two hospitals in 
Addis Ababa. Ethiop J Health Biomed Sci. 2009;2(1):3-8.

15. Gedebou ME, Kronvall G, Habte-Gabr EY, Ringertz SI. The bacteriology of nosocomial infections at Tikur Anbessa Teaching Hospital, Addis Ababa. Acta Pathologica Microbiologica Scandinavica Series B: Microbiology. 1987;95(1-6):331-6.

16. Tesfahunegn Z, Asrat D, Woldeamanuel Y, Estifanos K. Bacteriology of surgical site and catheter related urinary tract infections among patients admitted in Mekelle Hospital. Ethiop Med J. 2009;47:117-27.

Cite this article as: Latika, Nanda $S$, Dahiya $P$, Chaudhary S. Study of pattern of nosocomial infections among post-operative patients following obstetrical and gynaecological surgeries in a tertiary care institute of northern India. Int J Reprod Contracept Obstet Gynecol 2019;8:1421-5. 